\title{
Use of Metacognitive Strategies in Listening Comprehension by Iranian University Students Majoring in English: A Comparison between High and Low Proficient Listeners
}

\author{
Zahra Ratebi (Corresponding author) \\ Department of English Language, Faculty of Foreign Languages \\ University of Isfahan, Isfahan, Iran \\ E-mail: z.ratebi@yahoo.com
}

Zahra Amirian

Department of English Language, Faculty of Foreign Languages

University of Isfahan, Isfahan, Iran

E-mail: amirian_z@yahoo.com

Received: Dec. 28, 2012 Accepted: January 6, 2012 Published: February 1, 2013

doi:10.5296/jse.v3i1.2969 URL: http://dx.doi.org/10.5296/jse.v3i1.2969

\begin{abstract}
This study aimed to investigate the types of metacognitive strategies used by Iranian university students majoring in English, and the differences in the use of these strategies between listeners across two levels of high and low proficiency. The results revealed that Iranian university students used "problem-solving strategies" most frequently and "person-knowledge strategies" least frequently. It was also found that more proficient listeners used metacognitive strategies more frequently than less proficient listeners and there was a significant difference in the use of "person-knowledge strategies” between high and low proficient listeners. The results of the study have some implications for students, teachers, syllabus designers and EFL text book designers.
\end{abstract}

Keywords: Listening Comprehension, Learning Strategies, Metacognition, Metacognitive Strategies, EFL learner 


\section{Introduction}

Listening is an essential aspect of communicative competence and the most frequently used language skill (Richards, 2008). A large proportion of second and foreign language research findings indicated that listening is the most important skill for language learning, because it is the most widely used language skill in normal daily life (Morley, 2001; Rost, 2001). Listening is not only the first of the language skills developed, it is also the skill most frequently used in the classroom. In a language classroom, listening ability plays a significant role in the development of other language skills. Because students receive so much important language input aurally, they should work to develop aural proficiency skills and strategies to help them manage the listening comprehension process (Thompson \& Rubin, 1996; Hauck, 2005). The listening skill had been neglected until 1970s; since then, more attention has been paid to listening comprehension, and the status of listening has changed from being incidental and peripheral to a status of utmost importance. On the other hand, over the past 30 years, one of the most important topics in L2 and FL research has been the use and development of language learning strategies. Researchers such as Tarone (1980), O’Malley et al. (1985), Oxford (1990), Goh (2000) along with many others have examined a wide variety of issues related to learning strategies. Chamot (1987) stated that "learning strategies are techniques, approaches or deliberate actions that students take in order to facilitate the learning and recall of both linguistics and content area information" (P.71). Oxford (1990) added "Strategies are especially important for language learning, because they are tools for active, self-directed involvement, which is essential for developing communicative competence” (p.10). Nunan (1999) defined learning strategies as:

The mental and communicative procedures learners use in order to learn and use language. Underlying every learning task is at least one strategy. However, in most classrooms, learners are unaware of the strategies underlying the learning tasks in which they are engaged. (p.171)

Strategies have been described in different categories; most involve cognitive, metacognitive and social-affective categories. Cognitive strategies are behaviors, techniques, or actions used by learners to facilitate acquisition of knowledge or a skill. They are directly related to the performance of certain learning tasks e.g., elaboration, inferencing, and translation. Metacognitive learning strategies are those which involve knowing about learning and controlling learning through planning, monitoring and evaluating the learning activity. The social-affective strategies are a collection of strategies that involve the control of resources, time, effort and support. The social strategies include 'question for clarification' and 'cooperation' (O’Malley \& Chamot, 1990).

Metacognition plays a very important role in enhancing students' learning. John Flavell originally coined the term metacognition in the late 1970s to mean "cognition about cognitive phenomena,” or more simply “thinking about thinking” (Flavell, 1979, p.906). Metacognition consists of two components: knowledge and regulation (Cross \& Paris, 1988; Flavell, 1979). Metacognitive knowledge includes knowledge about oneself as a learner and about the factors that might impact performance (declarative), knowledge about strategies (procedural), and knowledge about when and why to use strategies (conditional) (Cross \& Paris, 1988; 
Kuhn \& Dean, 2004) . The other component of metacognition is regulating one's cognition, which many researchers (e.g. Cross \& Paris, 1988; Schraw et al., 2006; Whitebread et al. 2009) have argued includes activities of planning, monitoring, and evaluating. Metacognitive learning strategies help learners to know what to do when they come across difficulties. Metacognitive strategies are used to plan, monitor, and evaluate learning process, arrange the condition for someone to learn, set long and short term goals and check learners' comprehension during listening task (Oxford, 1990).

The present study focused on metacognitive strategies related to EFL listening comprehension at the university level. This study investigated the types of metacognitive strategies used by Iranian university students and examined whether there are any differences in the use of these strategies between more and less proficient listeners. In the following section, some of the studies concerning listening strategies in second or foreign language settings are presented.

\section{Literature Review}

Many researchers have examined the use of metacognitive strategies in listening comprehension process (e.g. Goh, 2000; Goh \& Taib, 2006; Mareschal, 2007; Graham \& Macaro, 2008; Cross, 2009; Vandergrift \& Tafaghodtari, 2010). All of them concurred that more proficient listeners use more metacognitive strategies and use of these strategies would improve the listening performance of language learners. Therefore, it is beneficial for language learners to be instructed to employ metacognitive strategies for listening tasks. Vandergrift is one of the researchers who have had a broad investigation in this field. Vandergrift (1996) investigated different listening strategies used by students at different levels. She found out that beginners mainly relied on semantic clues, cognates, kinesis and tone of voice together with cognitive strategies, such as elaboration and inferencing. On the other hand, intermediate level students used more metacognitive strategies and relied on similar cognitive strategies, although they were able to process a larger number of chunks. She concluded that the main characteristic of successful students is the use of more metacognitive strategies.

In another study conducted by Goh (1998), Chinese speakers studying English, initially took a listening and reading proficiency test. She used the results of the test to place students into two groups of high and low-proficiency. She interviewed students in each group and asked each of the students to record entries in a listening diary for eight weeks. From the interviews and the diaries, she made a list of strategies and converted the verbal information into numbers. Based on the analysis, Goh concluded that whereas the high-proficiency group used a broad range of strategies to comprehend the text, the low-proficiency group used a very small number of strategies.

Also in Vandergrift's (2003) investigation, which aimed to examine the relationship between listening proficiency and listening strategy use, 36 junior high school students of French in Canada were recruited for listening strategy elicitations. The study revealed that the more proficient listeners employed metacognitive strategies more frequently than the less proficient listeners did. Thus, the study suggests that teaching less proficient listeners to use 
metacognitive strategies would enhance their listening performance.

Another example of studies in an EFL setting is by Liu (2008) who studied the interrelationship among listening strategy use, listening proficiency levels, and learning style. A sample of 101 Taiwanese university EFL students from six classes was surveyed with two structured questionnaires of listening strategy use (O’Malley et al., 1985; Vandergrift, 1997) and learning style (Willing, 1988; Nunan, 1996). The results suggested that there was a statistically significant difference between the strategy use and the attainment levels. The findings also suggested that listening strategy use was significantly associated with learning styles.

There are a number of studies which investigated learning strategies in listening comprehension in Iranian context are also presented. One of these studies was conducted by Shirani Bidabadi and Yamat (2010) who explored the relationship between Iranian EFL freshmen's learning style preferences and the listening strategies they employ. 92 freshmen studying Teaching English as a Foreign Language were randomly selected from five classes from Shahid Beheshti University in Iran. Based on their scores on an Oxford Placement Test, their level of English listening proficiency was considered as intermediate. The adapted version of Listening Strategy and Learning Style Questionnaires were administered to identify the students' listening strategies and their learning style preferences. The descriptive analysis of the listening strategy questionnaire and learning style preferences indicated that these Iranian EFL freshmen employed metacognitive listening strategies such as planning, directed attention and selective attention the most and in terms of learning style preferences, they considered themselves as communicative learners.

Rahimi and Katal (2010) also investigated the level of Iranian university students' metacognitive listening strategies awareness in learning English by administering metacognitive awareness listening questionnaire (MALQ) among university students of different majors. The overall result showed that more than $60 \%$ of the participants were fully or considerably aware of their metacognitive listening strategies. It was also found that girls and boys were not different with regard to their general metacognitive awareness of listening strategies. However, girls' awareness in directed attention was significantly higher than boys' awareness. Further, English major students were found to be more aware of their problem solving and planning and evaluation strategies and non-English majors were found to be more aware of their mental translation strategies.

In another study, Rahimi and Katal (2011) investigated metacognitive listening strategies awareness among Iranian university and high school students. One hundred and twenty-two university students with different majors and one hundred and sixteen high school students, who were selected randomly from students of three universities and three high schools, filled in the Metacognitive Awareness Listening Questionnaire (MALQ). The results of the study showed that students in overall had a medium level of metacognitive listening strategies awareness. Further, more in-depth analysis of MALQ factors revealed that both groups are more aware of problem solving strategies than other strategy types; however, they are not aware of their person knowledge strategies. The authors resulted that it can be explained by 
considering the fact that it rarely happens that Iranian students have a chance to evaluate their own strengths with the given task in the language classes because most of the time, language courses in Iran focus on traditional techniques and teacher-centered methods (Rahimi and Nabilou, 2009). In addition, it was found that high school students were more aware of their metacognitive listening strategies in general in comparison to university students. This showed that unlike other studies (Vandergrift, 2005), the level of metacognitive awareness across age groups is different. This difference can be attributed to students' motivation, self-efficacy, and language listening skillfulness. Furthermore, high school students showed higher awareness in mental translation and person knowledge strategies. This was in line with findings of other researchers confirming that students of different levels with different abilities have significantly different metacognitive listening strategies awareness.

The present study has two aims: first, to investigate the total use of metacognitive listening strategies by Iranian university students at different levels of proficiency; second, to examine the differences in the use of metacognitive strategies in listening comprehension between high and low proficient listeners.

\section{Methodology}

\subsection{Participants}

Sixty freshman under-graduate students (23 males and 37 females), majoring in either English Language and Literature or English Translation whose first language was Persian and had not been yet to an English speaking country participated in this study. They were between the ages of 18 and 22 years old, studying at the Faculty of Foreign Languages at the University of Isfahan, Iran. They were selected based on a non-random purposive sampling technique because of the convenience and the availability of the sample.

\subsection{Instruments}

The first instrument used in this study was an International English Language Testing System (IELTS) listening test to assess the listening ability of the participants. The Listening part of IELTS consists of four sections, each with ten questions. The first two sections concerns with social needs. The final two sections concerns with situations related to educational or training contexts. A variety of question types is used, such as multiple choice, matching, form completion, sentence completion, and short answer questions. Based on the standards of the IELTS, these 40 items in 4 sections take approximately 30 minutes for candidates to answer as they listen. Ten minutes are allowed at the end to transfer the answers to the answer sheet. Each question in the listening test is worth one mark. The maximum raw score a candidate can achieve on a paper is 40. IELTS results are reported on a nine-band scale (Available on the website www.ielts.org).

The second instrument was Metacognitive Awareness Listening Questionnaire (MALQ) (Vandergrift, et al., 2006) to assess second and foreign language learners' metacognitive awareness and perceived use of strategies in listening comprehension. The questionnaire contains 21 items, each item is rated on a six point Likert scale ranging from 1(strongly disagree) to 6(strongly agree) without a neutral point so that respondents could not hedge. 
MALQ consists of five categories including problem solving (6 items), planning and evaluation (5 items), mental translation (4 items), person knowledge (3 items) and directed attention (4 items). The validity of the questionnaire has been explored by the developers using both exploratory and confirmatory analysis by a large sample of different foreign language learners including Iranians (Vandergrift, et al., 2006).

\subsection{Procedure}

In order to conduct the study, after talking to the instructors, in spring 2012, 60 freshman students were selected at the University of Isfahan, faculty of foreign languages, English Language department. At first, an IELTS listening test was given to the students. Before the test administration, the instructions of all four sections of the test and the way of answering the questions in the answer sheet were explained by the researcher. Based on the raw scores in the test, students were divided into two groups of high proficient and low proficient listeners. Accordingly, band scores ranging from Band 1 to Band 9 were awarded on the basis of the raw scores. The participants were divided into those who got grade 6 or higher as high proficient listeners, and those who scored lower as low proficient listeners, considering the widespread use of this value as a criterion for entry in to universities around the world.

The MALQ questionnaire was administered immediately after the test to the participants in both groups. In this way, they were engaged in an authentic listening activity and they had a specific task on which to base their responses. It was announced that this is not a test with 'right' or 'wrong' answers and their responses to the questionnaire would not affect their scores on the final exam. It was also stated that their forthright and honest responses were important and that confidentiality would be respected. They were required to circle the numbers on the Likert scale to best show their level of agreement with the statement. It took the participants approximately 15 minutes to complete. After the completion, the questionnaires were collected and returned to the researcher for the data analysis.

\section{Results}

According to the data collected through MALQ, the total average scores in MALQ was 4.07, and the mean of MALQ subscales ranged from 2.89 to 4.30, implying the highest level of metacognitive awareness for "Problem Solving" strategy and the lowest level of awareness for "Person Knowledge" strategy. The results of the MALQ and its subparts are summarized in Table 1.

Table 1. Distribution of Mean Scores on MALQ and Its Subparts ( $\mathrm{n}=60)$

\begin{tabular}{lccccc}
\hline Scale & Number of items & Possible range & Mean & SD & Average per item \\
\hline Planning-evaluation & 5 & $5-30$ & 19.13 & 4.62 & 3.83 \\
Directed attention & 4 & $4-20$ & 16.7 & 5.54 & 4.17 \\
Person knowledge & 3 & $4-20$ & 11.58 & 3.23 & 2.89 \\
Mental translation & 3 & $3-15$ & 12.17 & 3.58 & 4.05 \\
Problem solving & 6 & $6-36$ & 25.83 & 5.05 & 4.30 \\
MALQ & 21 & $21-144$ & 85.42 & 11.95 & 4.07 \\
\hline
\end{tabular}


Table 2 shows the statistics of the participants' listening test scores in each group; as indicated in this table, 20 of the participants were regarded as low proficient listeners and 40 of them as high proficient listeners.

Table 2. Division of the Participants in Two Groups

\begin{tabular}{cccccc}
\hline \multirow{2}{*}{ Level } & \multirow{2}{*}{ Band score } & \multicolumn{5}{c}{ Listening Score } \\
\cline { 3 - 6 } & 4 & Mean & Maximum & Minimum & Total N \\
\hline \multirow{2}{*}{ Low } & 4 & 13 & 15 & 10 & 9 \\
& 5 & 19 & 22 & 16 & 11 \\
\hline \multirow{3}{*}{ High } & 6 & 26 & 29 & 23 & 20 \\
& 7 & 32 & 34 & 30 & 14 \\
& 8 & 36 & 37 & 35 & 6 \\
\hline
\end{tabular}

In order to find out the differences in the use of metacognitive strategies between two groups of low and high proficient listeners, a series of one way ANOVAs were conducted. As indicated in Table 3, the mean scores of high proficient listeners in all categories are higher than the mean scores of less proficient listeners, except for the "Mental Translation" category.

The total mean score of the listeners in high proficiency group is 87.18 in comparison to the mean score of the listeners in low proficiency group (81.90). It shows that high proficient listeners use far more metacognitive strategies compared with less proficient listeners.

Table 3. Descriptive Statistics of MALQ Subsections between High and Low Proficient Listeners

\begin{tabular}{|c|c|c|c|c|c|c|c|c|c|}
\hline & & \multirow[b]{2}{*}{$\mathrm{N}$} & \multirow[b]{2}{*}{ Mean } & \multirow[b]{2}{*}{$\begin{array}{c}\text { Std. } \\
\text { Deviation }\end{array}$} & \multirow[b]{2}{*}{$\begin{array}{l}\text { Std. } \\
\text { Error }\end{array}$} & \multicolumn{2}{|c|}{$\begin{array}{l}\text { 95\% Confidence } \\
\text { Interval for Mean }\end{array}$} & \multirow[b]{2}{*}{ Min } & \multirow[b]{2}{*}{ Max } \\
\hline & & & & & & $\begin{array}{l}\text { Lower } \\
\text { Bound }\end{array}$ & $\begin{array}{l}\text { Upper } \\
\text { Bound }\end{array}$ & & \\
\hline \multirow{3}{*}{$\begin{array}{l}\text { Planning - } \\
\text { evaluation }\end{array}$} & Low & 20 & 18.45 & 5.326 & 1.191 & 15.96 & 20.94 & 8 & 28 \\
\hline & High & 40 & 19.48 & 4.261 & .674 & 18.11 & 20.84 & 7 & 28 \\
\hline & Total & 60 & 19.13 & 4.623 & .597 & 17.94 & 20.33 & 7 & 28 \\
\hline \multirow{3}{*}{$\begin{array}{l}\text { Directed } \\
\text { attention }\end{array}$} & Low & 20 & 15.40 & 4.925 & 1.101 & 13.10 & 17.70 & 4 & 24 \\
\hline & High & 40 & 17.35 & 4.246 & .671 & 15.99 & 18.71 & 9 & 24 \\
\hline & Total & 60 & 16.70 & 4.537 & .586 & 15.53 & 17.87 & 4 & 24 \\
\hline \multirow{3}{*}{$\begin{array}{c}\text { Person } \\
\text { knowledge }\end{array}$} & Low & 20 & 10.10 & 3.227 & .721 & 8.59 & 11.61 & 6 & 16 \\
\hline & High & 40 & 12.33 & 2.999 & .474 & 11.37 & 13.28 & 6 & 18 \\
\hline & Total & 60 & 11.58 & 3.227 & .417 & 10.75 & 12.42 & 6 & 18 \\
\hline \multirow{3}{*}{$\begin{array}{c}\text { Mental } \\
\text { translation }\end{array}$} & Low & 20 & 12.55 & 3.859 & .863 & 10.74 & 14.36 & 4 & 18 \\
\hline & High & 40 & 11.98 & 3.460 & .547 & 10.87 & 13.08 & 4 & 18 \\
\hline & Total & 60 & 12.17 & 3.576 & .462 & 11.24 & 13.09 & 4 & 18 \\
\hline \multirow{3}{*}{$\begin{array}{l}\text { Problem - } \\
\text { solving }\end{array}$} & Low & 20 & 25.40 & 4.925 & 1.101 & 23.10 & 27.70 & 14 & 36 \\
\hline & High & 40 & 26.05 & 5.164 & .816 & 24.40 & 27.70 & 13 & 36 \\
\hline & Total & 60 & 25.83 & 5.053 & .652 & 24.53 & 27.14 & 13 & 36 \\
\hline \multirow{3}{*}{$\begin{array}{l}\text { MALQ total } \\
\text { score }\end{array}$} & Low & 20 & 81.90 & 11.916 & 2.664 & 76.32 & 87.48 & 59 & 109 \\
\hline & High & 40 & 87.18 & 11.714 & 1.852 & 83.43 & 90.92 & 64 & 110 \\
\hline & Total & 60 & 85.42 & 11.947 & 1.542 & 82.33 & 88.50 & 59 & 110 \\
\hline
\end{tabular}


As shown in Table 4, analysis of the one-way ANOVAs showed that there was no significant difference in the use of metacognitive strategies between two groups of listeners except for "Person Knowledge" strategy $(\mathrm{F}=6.979, \mathrm{p}=.011)$. The use of this strategy for high proficient listeners had the highest mean score $(\mathrm{M}=12.33, \mathrm{SD}=2.999)$ as compared to the mean score in low proficiency group ( $\mathrm{M}=10.10, \mathrm{SD}=3.227)$. The effect size, calculated using eta squared, was 0.17, which in Cohen's (1988) term, would be considered as a large effect.

Table 4. The Result of One Way ANOVAs between Two Groups

\begin{tabular}{|c|c|c|c|c|c|c|}
\hline & & $\begin{array}{l}\text { Sum of } \\
\text { Squares }\end{array}$ & Df & $\begin{array}{c}\text { Mean } \\
\text { Square }\end{array}$ & $\mathrm{F}$ & Sig. \\
\hline \multirow[t]{3}{*}{ Planning - evaluation } & Between Groups & 14.008 & 1 & 14.008 & .652 & .423 \\
\hline & Within Groups & 1246.925 & 58 & 21.499 & & \\
\hline & Total & 1260.933 & 59 & & & \\
\hline \multirow[t]{3}{*}{ Directed attention } & Between Groups & 50.700 & 1 & 50.700 & 2.527 & .117 \\
\hline & Within Groups & 1163.900 & 58 & 20.067 & & \\
\hline & Total & 1214.600 & 59 & & & \\
\hline \multirow[t]{3}{*}{ Person knowledge } & Between Groups & 66.008 & 1 & 66.008 & 6.979 & .011 \\
\hline & Within Groups & 548.575 & 58 & 9.458 & & \\
\hline & Total & 614.583 & 59 & & & \\
\hline \multirow[t]{3}{*}{ Mental translation } & Between Groups & 4.408 & 1 & 4.408 & .341 & .562 \\
\hline & Within Groups & 749.925 & 58 & 12.930 & & \\
\hline & Total & 754.333 & 59 & & & \\
\hline \multirow[t]{3}{*}{ Problem-solving } & Between Groups & 5.633 & 1 & 5.633 & .218 & .643 \\
\hline & Within Groups & 1500.700 & 58 & 25.874 & & \\
\hline & Total & 1506.333 & 59 & & & \\
\hline \multirow[t]{3}{*}{ MALQ total score } & Between Groups & 371.008 & 1 & 371.008 & 2.673 & .107 \\
\hline & Within Groups & 8049.575 & 58 & 138.786 & & \\
\hline & Total & 8420.583 & 59 & & & \\
\hline
\end{tabular}

Figure 1 displays the obtained results of the comparison of the use of metacognitive strategies across two levels of listening proficiency. 


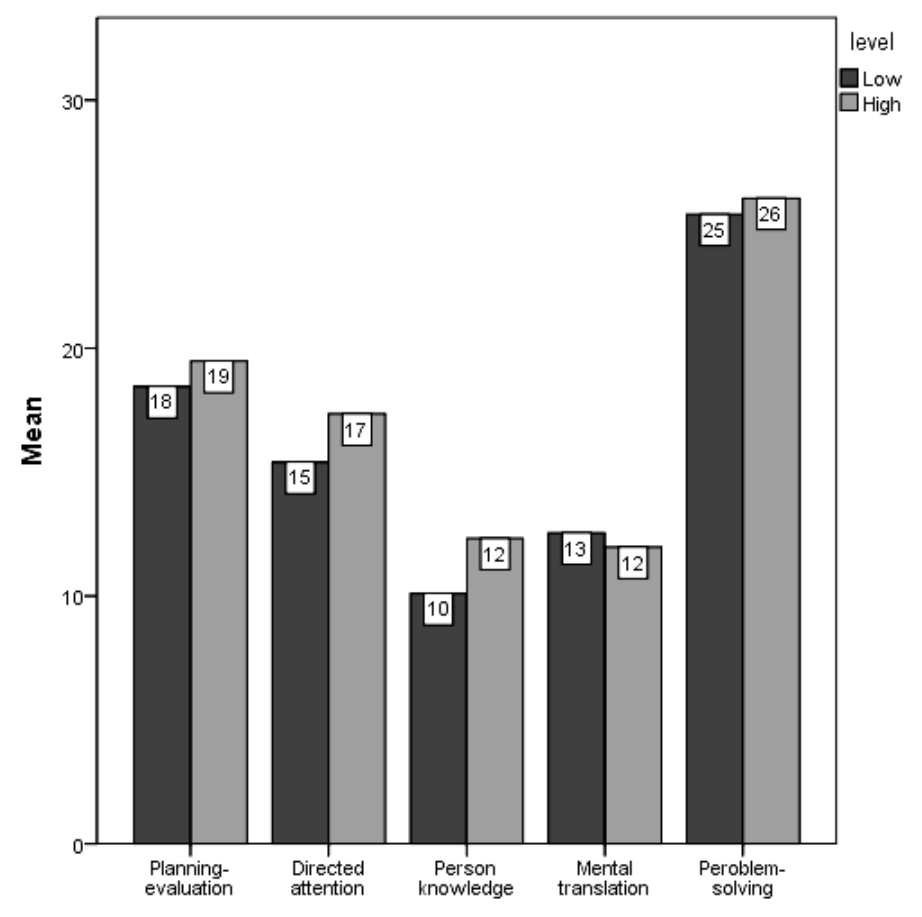

Figure 1. The comparison on the use of metacognitive strategies between high and low proficient listeners

\section{Discussion}

This study investigated the types of metacognitive strategies in listening comprehension used by Iranian university students. The study was motivated by previous findings showing that proficient listeners use more metacognitive strategies than less proficient listeners. The study was, therefore, an attempt to find out whether such findings could be confirmed in Iranian EFL setting. In this study, IELTS listening tests were used to measure the listening ability of the participants. The aim of this test has generally been to evaluate whether the listeners have the ability to communicate in the target-language use (TLU) domains (Bachman \& Palmer, 1996, p. 18), that is "the real world situation in which the language will be used" (Buck, 2001, p. 83). To the extent that the students may not accurately reflect the entire population of EFL students, the interpretation of the results of this study could not be generalized.

The results of this study demonstrated that students' level of metacognitive listening strategy awareness is satisfactory. This is in line with finding of other studies that showed Iranian students have rather high metacognitive awareness in listening strategies (Rahimi \& katal, 2011; ShiraniBidabadi \& Yamat, 2010). Furthermore, in this study and the study done by Rahimi and Katal (2012), the highest level of metacognitive awareness is for "problem-solving" strategies (4.30, 4.44 respectively) and the lowest level of awareness is for “person knowledge” strategies (2.89, 2.56 respectively).

Among the five main categories of metacognitive strategies in MALQ, the category of "problem solving" was the first most frequently used; and "directed attention" was the metacognitive strategy of second highest frequency. The third and fourth most categories included "Mental translation" and "Planning-evaluation". And the last category of "Person 
knowledge" was the metacognitive strategy of the least frequency.

Six items representing problem-solving strategies, the first most frequently used metacognitive strategy, include a group of strategies listeners use to make inferences and to monitor these inferences. According to Vandergrift (2003) and Goh (2000), metacognitive strategies, such as monitoring and problem solving are used by students when they regularly translate what is heard. These strategies represent the problem-solving processes, the knowledge retrieval processes, and the accompanying verification (monitoring) processes (Kintsch, 1998, p. 189). The second highest strategy awareness was for directed attention (4.17) which represents strategies that listeners use to concentrate and to stay on task such as getting back on track when losing concentration or focusing harder when having difficulty understanding (Rost, 2002). The third highest strategy awareness was for "mental translation strategies” (4.05) which include strategies that listeners must learn to avoid if they are to become skilled listeners (Vandergrift, 2003).

The least frequently used strategy was for "Person knowledge" strategies which include items assessing the perceived difficulty of listening compared with the three other language skills, learners' linguistic confidence in second or foreign language listening, and the anxiety level experienced in second or foreign language listening (Sparks \& Ganschow, 2001). It shows that Iranian EFL learners have a low level of confidence and self-efficacy in listening comprehension and they perceive listening skill harder than other skills. Maybe, it can be said that because Iranian learners consider listening as a difficult task to do, they concentrate with difficulty and they try to do their best in this regard. The second lowest strategy awareness was for "planning-evaluation strategies" (3.83) which are those types of strategies that listeners use to prepare themselves for listening and to evaluate the results of their listening efforts. These strategies represent the purposeful nature of the comprehension process and the evaluation of the comprehension goals (Richards, 1983). It seems that Iranian students do not have enough awareness of these types of strategies (two last categories, planning-evaluation and person knowledge) and need to develop strategy awareness through explicit instruction. EFL teachers should teach their students how to listen, to reflect on the process of listening and focus on using the metacognitive strategies of planning and monitoring and evaluation.

In addition, the study found that more proficient listeners employed metacognitive strategies more frequently than less proficient listeners did. This finding suggests that less proficient EFL listeners should be made aware of these strategies and be instructed to make use of them to improve their listening comprehension.

According to research on listening comprehension (Berne, 2004; Flowerdew \& Miller, 2005; Goh, 2000; Mendelsohn, 1995; Vandergrift, 2003), all EFL learners use some strategies to help them understand an oral English text. More proficient EFL listeners are more aware of the strategies that they use and employ these strategies more effectively than less proficient EFL listeners. The results of this study showed that more proficient listeners tended to use metacognitive strategies of planning-evaluation, directed attention, person knowledge, and problem-solving more frequently than less proficient listeners. However, less proficient listeners employed more metacognitive listening strategies of mental translation than 
proficient listeners did. Vandergrift (2003) defined mental translation strategies as those strategies that listeners must learn to avoid if they are to become skilled listeners. These strategies represent an inefficient approach to listening comprehension that beginning-level listeners often feel compelled to use (Eastman, 1991). Accordingly, less proficient listeners tended to use "mental translation strategies" more than more proficient listeners.

Among these strategies, the use of “person knowledge” strategy by more proficient listeners compared to less proficient listeners reached the significance $(\mathrm{p}<.05)$.i.e. there was a significant difference in the use of "person knowledge" strategy between less and more proficient listeners. In this regard, it was revealed that less proficient listeners are less aware of this strategy and they have lower level of confidence so that they experience higher level of anxiety during listening task, resulting in impediment in listening comprehension.

Rost (2002) demonstrated that the use of metacognitive strategies (planning for listening, self-monitoring of comprehension process and evaluation of one's own performance) is associated with proficient listeners. So, proficient listeners' performance and strategy use, could provide valuable instructional resources and useful teaching guidelines for teachers. Therefore, teachers can base their listening instruction on proficient listeners' use of metacognitive strategies as a model to design various practical tasks, for guiding listeners to have better use of metacognitive listening strategies (Goh, 2000; Vandergrift, 2004). As Graham (2006) stated students need to acquire a proper perception of their effective strategies and apply them in listening as they confidently approach listening inputs to achieve the most in listening performance.

\section{Conclusion}

This study investigated the types of metacognitive strategies used by Iranian university students and the differences in the use of these strategies between more and less proficient listeners. The results of the study can be considered another contribution towards supporting the use and training of metacognitive strategies in language learning during listening comprehension process.

This study added to the meager body of metacognitive strategies for listening comprehension research that had been conducted in foreign language acquisition literature in Iranian EFL setting.

The participants of this study were limited to freshman students of English Literature and English translation at the University of Isfahan, other levels were not included. Thus, the findings cannot be generalized to higher levels. The results of this study have some implications for students, teachers, syllabus designers and text book designers. This study may encourage further awareness of metacognitive strategies for EFL learners to improve their listening comprehension. The findings of this study also can convince the language teachers to pay more attention to the metacognitive strategies as a part of learning strategies for listening comprehension. In conclusion, it is important that EFL teachers emphasize listening in the foreign language instruction and they should increase the amount of listening time in EFL classes. It is clear that research related to listening comprehension strategies 
provide a wealth of information. Many questions remain unaddressed and as a result, listening comprehension strategies will remain a vital and fertile field for researchers to explore.

\section{References}

Bachman, L. F., \& Palmer, A. (1996). Language testing in practice. Oxford: Oxford University Press.

Berne, J. E. (2004). Listening comprehension strategies: A review of the literature. Foreign Language Annals, 37, 521- 533.

Buck, G. (2001). Assessing listening. Cambridge: Cambridge University Press. http://dx.doi.org/10.1017/CBO9780511732959

Chamot, A. (1987). The learning strategies of ESL students. In A. Wenden \& J. Rubin (Eds.), Learner strategies in language learning (pp. 71-83). New York: Prentice Hall.

Cross, D. R. \& Paris, S. G. (1988). Developmental and instructional analyses of children's metacognition and reading comprehension. Journal of Educational Psychology, 80(2), 131-142. http://dx.doi.org/10.1037/0022-0663.80.2.131

Cross, J. D. (2009). Effects of listening strategy instruction on news videotext comprehension. Language Teaching Research, 13, 151-176. http://dx.doi.org/10.1177/1362168809103446

Eastman, J. K. (1991). Learning to listen and comprehend: the beginning stages. System 19(3), 179-87. http://dx.doi.org/10.1016/0346-251X(91)90042-N

Flavell, J. H. (1979). Metacognition and cognitive monitoring: A new area of cognitive developmental inquiry. American Psychologist, 34, 906- 911. http://dx.doi.org/10.1037/0003-066X.34.10.906

Flowerdew, J. H., \& Miller, L. (2005). Second language listening: Theory and practice. NewYork: Cambridge University Press.

Goh, C. (1998). How ESL learners with different listening abilities use comprehension strategies and tactics. Language Teaching Research, 2, 124-147. Retrieved from

Goh, C. (2000). A cognitive perspective on language learners' listening comprehension problems, Systems, 28, 55-75.

Goh, C., \& Taib, Y. (2006). Metacognitive instruction in listening for young learners. ELT Journal, 60, 222-232. http://dx.doi.org/10.1093/elt/ccl002

Graham, S. (2006). Listening comprehension: The learners’ perspective. System, 34, 165-182. http://dx.doi.org/10.1016/j.system.2005.11.001

Graham, S., \& Macaro, E. (2008). Strategy instruction in listening for lower-intermediate learners of French. Language Learning, 58, 747-783. http://dx.doi.org/10.1111/j.1467-9922.2008.00478.x 
Hauck, M. (2005). Metacognitive knowledge, metacognitive strategies and CALL. In J. Egbert and G. Petrie (Eds.), CALL research perspectives (pp. 65-86). Mahwah, NJ: Lawrence Erlbaum Associates.

Kintsch, W. (1998). Comprehension: A paradigm for cognition. Cambridge, UK: Cambridge University Press.

Kuhn, D., \& Dean, D. (2004). A bridge between cognitive psychology and educational $\begin{array}{llll}\text { practice. Theory into } & \text { 268-273. }\end{array}$ http://dx.doi.org/10.1207/s15430421tip4304_4

Liu, H. J. (2008). A study of the interrelationship between listening strategy use, listening proficiency levels, and learning style. RARECLS, 5, 84-104.

Mareschal, C. (2007). Student perceptions of a self-regulatory approach to second language listening comprehension development. $\mathrm{PhD} \mathrm{PhD}$, University of Ottawa,Ottawa.

Mendelsohn, D. (1995). Applying learning strategies in the second/ foreign language listening comprehension lesson. In D. Mendelsohn \& J. Rubin (Eds.), A guide for the teaching of second language listening (pp. 132-150). San Diego: Dominie Press.

Nunan, D. (1996). What's my style? In D. Gardner and L. Miller (eds.), Tasks for independent language learning. Alexandria: TESOL.

Nunan, D. (1999). Second language teaching and learning: Heinle and Heinle. An International Thomson Publish Boston, Massachusetts 02116 U.S.A.

O’Malley, J. M., Chamot, A. U., Stewner-Manzanares, G., Kupper, L., \& Russo, R. (1985). Learning strategies used by beginning and intermediate ESL students. Language Learning, 35(1), 21-46. http://dx.doi.org/10.1111/j.1467-1770.1985.tb01013.x

O’Malley, J. M., \& Chamot, A. U. (1990). Learning strategies in second language acquisition. Cambridge: Cambridge University Press. http://dx.doi.org/10.1017/CBO9781139524490

Oxford, R. (1990). Language learning strategies: What every teacher should know. New York: Newbury House.

Rahimi, M., \& Nabilou, Z. (2009). Globalization and EFL Curriculum Reform in Iran: Challenges and Opportunities. Journal of Technology of Education, 3, 115-124.

Rahimi, M. and Katal, M. (2010, May).Iranian university students' metacognitive listening strategies awareness in learning English. Paper presented at the third national conference on education, Tehran, Iran.

Rahimi, M. and Katal, M. (2011). Metacognitive strategies awareness and success in learning English as a foreign language: an overview. Procedia - Social and Behavioral Sciences 31 (2012) 73 - 81. http://dx.doi.org/10.1016/j.sbspro.2011.12.019

Richards, J. C. (1983). Listening comprehension: Approach, design, procedure. TESOL 
Quarterly, 17, 219-240. http://dx.doi.org/10.2307/3586651

Richards, J. C. (2008). Teaching listening and speaking from theory to practice. Cambridge: Cambridge University Press.

Rost, M. (2002). Teaching and researching listening. London, UK: Longman.

Schraw, G., Crippen, K. J., \& Hartley, K. (2006). Promoting self-regulation in science education: Metacognition as part of a broader perspective on learning. Research in Science Education, 36, 111-139. http://dx.doi.org/10.1007/s11165-005-3917-8

ShiraniBidabadi, F., and Yamat, H. (2010).The Relationship between Listening Strategies Employed by Iranian EFL Freshman University Students and their Learning Style Preferences. European Journal of Social Sciences, 16(3), 342-351.

Tarone, E. (1980). Communication strategies, foreigner talk and repair in interlanguage. Language Learning, 30, 417-431. http://dx.doi.org/10.1111/j.1467-1770.1980.tb00326.x

Thompson, I., \& Rubin, J. (1996). Can strategy instruction improve listening comprehension? Foreign Language Annals, 331-341. http://dx.doi.org/10.1111/j.1944-9720.1996.tb01246.x

Vandergrift, L. (1996). Listening strategies of core French high school students. Canadian Modern Language Review, 52, 200-223.

Vandergrift, L. (1997). The strategies of second language (French) listeners. Foreign Language Annals, 30, 387-409. http://dx.doi.org/10.1111/j.1944-9720.1997.tb02362.x

Vandergrift, L. (2003). Orchestrating strategy use: Towards a model of the skilled L2 listener. Language learning, 53, 461- 491. http://dx.doi.org/10.1111/1467-9922.00232

Vandergrift, L. (2004). Learning to listen or listening to learn. Annual Review of Applied Linguistics, 24, 3-25.

Vandergrift, L. (2005). Relationships among motivation orientations, metacognitive awareness and proficiency in L2 listening. Applied linguistics, 26, 70-89. doi:10.1093/applin/amh 03979

Vandergrift, L., Goh, C., Mareschal, C., \& Tafaghodtari, M. H. (2006). The Metacognitive Awareness Listening Questionnaire (MALQ): Development and validation. Language Learning, 56, 431-462. http://dx.doi.org/10.1111/j.1467-9922.2006.00373.x

Vandergrift, L., \& Tafaghodtari, M. (2010). Teaching L2 Learners How to Listen Does Make a Difference: An Empirical Study. Language Learning, 60, 470-467. http://dx.doi.org/10.1111/j.1467-9922.2009.00559.x

Whitebread, D., Coltman, P., Pasternak, D. P., Sangster, C., Grau, V., Bingham, S., Almeqdad, Q., \& Demetriou, D. (2009). The development of two observational tools for assessing metacognition and self-regulated learning in young children. Metacognition and Learning, 4(1), 63-85. http://dx.doi.org/10.1007/s11409-008-9033-1 


\section{Macrothink}

Journal of Studies in Education

ISSN 2162-6952

2013, Vol. 3, No. 1

Willing, K. (1988). Learning styles in adult migrant education. Sydney: Macquarie University.

\section{Copyright Disclaimer}

Copyright reserved by the author(s).

This article is an open-access article distributed under the terms and conditions of the Creative Commons Attribution license (http://creativecommons.org/licenses/by/3.0/). 